\title{
Complications and treatment of superficial thrombophlebitis
}

\author{
Complicações e tratamento da tromboflebite superficial
}

Marcone Lima Sobreira ${ }^{\top}$

Superficial thrombophlebitis (ST) of the lower limbs, also known as superficial venous thrombosis, is a condition in which there is a thrombus in the lumen of a superficial vein and an inflammatory reaction in the vessel wall and neighboring tissues. It presents as a palpable cord that is hard, hyperemic, hot and painful and follows the path of a superficial vein. ${ }^{1}$ The condition is common, but its exact incidence is unknown. It is estimated that it has a greater incidence than deep venous thrombosis (DVT). ${ }^{2}$

Clinical diagnosis is very accurate, but vascular ultrasonography can improve accuracy further and can show the extent of the thrombotic process. The amplitude of the inflammatory process varies, but can affect vessels ranging from minor tributaries to large sections of the saphenous trunks; and, in more severe cases, can involve the deep vein system, causing severe thromboembolic complications, such as deep vein thrombosis (DVT) and pulmonary embolism (PE) ${ }^{3,4}$ From $21.6 \%$ to $36 \%$ of ST cases present concomitant DVT. ${ }^{5}$ In turn, in studies that have conducted systematic screening irrespective of the presence or absence of symptoms, superficial thrombophlebitis has been detected coexisting with pulmonary embolism in up to $28 \%$ of some case series described in the literature. ${ }^{5,6}$

Certain clinical characteristics appear to be related to an increased risk of thromboembolic complications, including: male sex, age $>60$ years, prior history of DVT, bilateral ST and infection. ${ }^{7}$ Other characteristics, such as proximity of the thrombotic process to the deep vein system, do not appear to elevate the risk of thromboembolic complications..$^{5,8}$ The association of ST with thromboembolic complications has raised doubts about the benign nature of the condition, and use of vascular ultrasonography to conduct more thorough investigations is recommended more and more. In one study conducted at our service (Botucatu Medical School-UNESP, SP, Brazil), the incidence of DVT associated with cases of ST compromising lower limbs was $21.67 \%$, while the rate of symptomatic PE was $35.3 \% .^{5}$ These figures call attention to the fact that ST is not a benign condition with selflimiting behavior, but probably includes an element of subclinical hypercoagulability, especially when involving non-varicose veins, which can increase the risk of concomitant DVT by more than nine times. ${ }^{5}$ It is important to note that, in addition to its associations with DVT and PE, ST can also be predictive of arteriopathies and neoplasms, a marker of thrombophilia and a marker of recurrent thromboembolic phenomena.

Some authors believe that even in patients with varicose veins (a condition of known risk for ST) emergence of ST is not always merely a simple accident of disease progression. ${ }^{9}$ In a study conducted at our institution (currently unpublished), approximately $60 \%$ of cases of thrombophlebitis exhibited associations with at least one prothrombotic disorder, among which factor V Leiden (39.30\%) and prothrombin G20210A gene mutations $(19.70 \%)$ were the most common.

It is also important to bear in mind that this pathology has a strong association as a clinical predictor of certain forms of neoplasm, according to some authors (the Trousseau syndrome), in particular of the stomach, pancreas, colon, lungs, breasts, ovaries and prostate. ${ }^{1}$ This is however unproven and in a recent French study, ST was not found to be an independent predictor of neoplasm. ${ }^{10}$

The scarcity of well-designed studies investigating ST has led to a heterogeneous body of conflicting results, which has not adequately revealed the natural history of ST and describes a large number of treatment options, without, however, providing any significant evidence for the relevance of any of them. Clinical approaches that have been described include: recommending walking and rest in the Trendelemburg position, non-steroidal anti-inflammatories, elastic compression, anticoagulation (prophylactic or therapeutic) and topical treatments. Of these options, those that appear to offer potential benefits are anticoagulant treatment (although there is no consensus whether dosages should be prophylactic or therapeutic) and anti-inflammatories. 
The miscellany of conflicting results is reflected in the consensus guidelines on treating the condition. Successive pronouncements of the American College of Chest Physicians (ACCP) illustrate this:

- CHEST 2004 (7th edition): ${ }^{11}$ If ST is triggered by intravenous infusion, systemic (2B) or topical (1B) anti-inflammatories are recommended. If $\mathrm{ST}$ is spontaneous, the recommendation is unfractionated or low molecular weight heparin for a minimum of 4 weeks (2B).

- CHEST 2008 (8th edition): ${ }^{12}$ Suggests combining anti-inflammatories with anticoagulant treatment (2B). Emphasizes the recommendation that when the ST thrombotic process is distant from the connection with the deep vein system, topical or systemic anti-inflammatory treatment should be prescribed (2C).

- CHEST 2012 (9th edition): ${ }^{13}$ Anti-inflammatories are relegated to the second option, and the recommendation is that treatment should be with fondaparinux or low molecular weight heparin in prophylactic doses, if the thrombotic process is $>5 \mathrm{~cm}$ long (2B).

What becomes clear from these three editions of the consensus is that there is a preference for clinical treatment and surgical treatment is only recommended on one occasion, as offering more rapid relief from symptoms. ${ }^{12}$ This could be the result of poorly designed studies to investigate surgical treatment. When the issue was analyzed using Cochrane evidence-based medicine methods in a systematic review of 30 studies (6,507 patients), the authors recommended anticoagulant treatment with fondaparinux (prophylactic dose) for treatment of ST and reported that there was not enough evidence to recommend any of the other treatment options topical, systemic or surgical - and particularly not with respect to progression of the thrombus or to thromboembolic complications. ${ }^{14}$

Our team's experience has led us to prefer clinical treatment as the first approach, reserving surgery for patients with varicose veins (Figure 1).

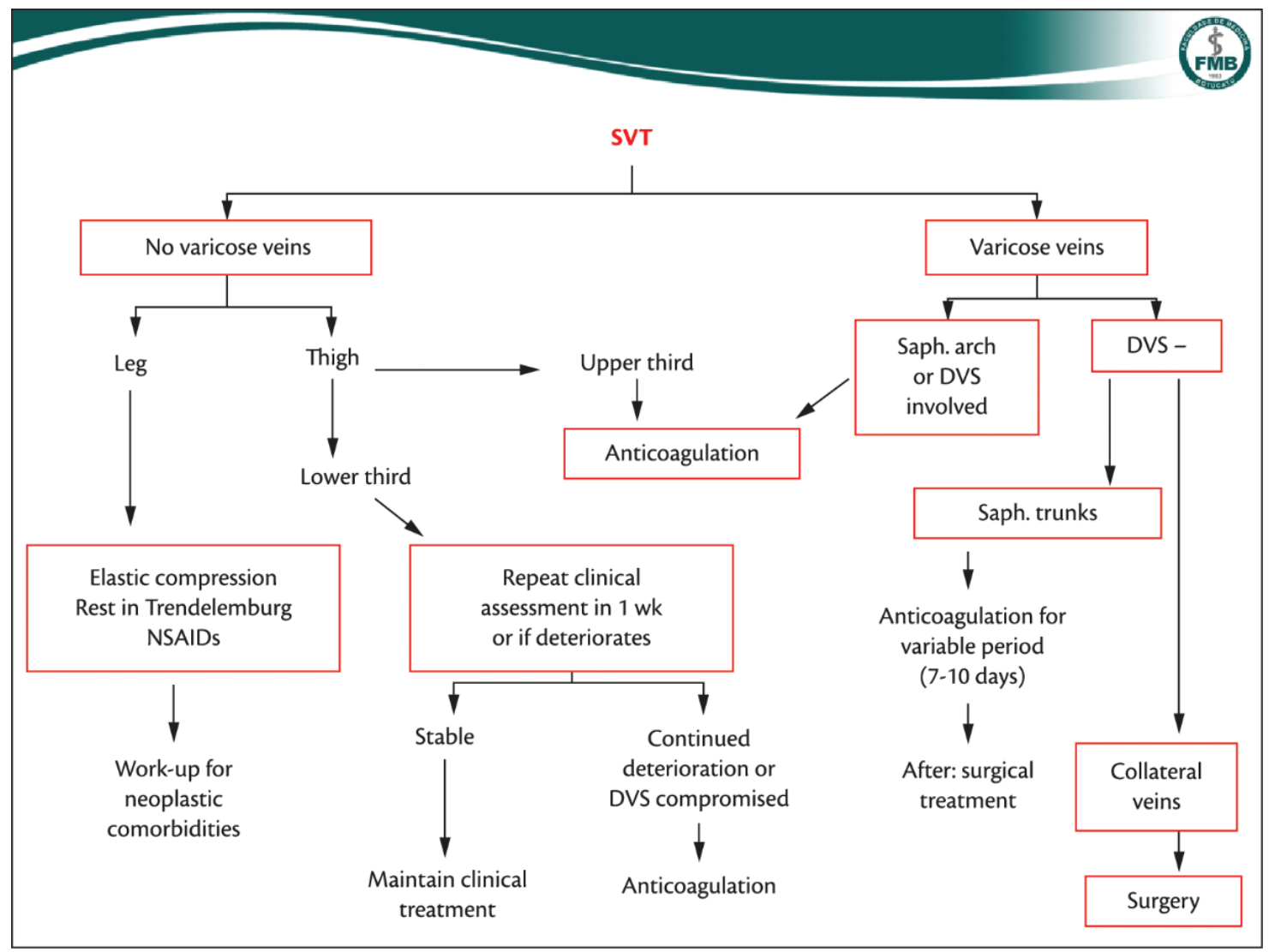

Figure 1. Treatment approach to superficial venous thrombosis (SVT) as used at the Vascular and Endovascular Surgery Service, Faculdade de Medicina de Botucatu, UNESP, Brazil. DVS = deep vein system. 


\section{REFERENCES}

1. Sobreira ML, Yoshida WB, Lastória S. Tromboflebite superficial: epidemiologia, fisiopatologia, diagnóstico e tratamento. J Vasc Bras. 2008;7(2):131-43.

2. Nordström $M$, Lindblad B, Bergqvist D, Kjellström T. A prospective study of the incidence of deep-vein thrombosis within a defined urban population. J Intern Med. 1992;232(2):155-60. http://dx.doi. org/10.1111/j.1365-2796.1992.tb00565.x. PMid:1506812

3. Jorgensen JO, Hanel KC, Morgan AM, Hunt JM. The incidence of deep venous thrombosis in patients with superficial thrombophlebitis of the lower limbs. J Vasc Surg. 1993;18(1):70-3. http://dx.doi. org/10.1067/mva.1993.42072. PMid:8326661

4. Blumenberg RM, Barton E, Gelfand ML, Skudder P, Brennan J. Occult deep venous thrombosis complicating superficial thrombophlebitis. J Vasc Surg. 1998;27(2):338-43. http://dx.doi. org/10.1016/S0741-5214(98)70364-7. PMid:9510288

5. Sobreira ML, Maffei FHA, Yoshida WB, et al. Prevalence of deep vein thrombosis and pulmonary embolism in superficial thrombophlebitis of the lower limbs: prospective study of 60 cases. Int Angiol. 2009;28(5):400-8. PMid:19935595.

6. Verlato F, Zucchetta P, Prandoni P, et al. An unexpectdly high rate of pulmonary embolism in patients with superficial thrombophlebitis of the thigh. J Vasc Surg. 1999;30(6):1113-5. PMID: 10587397.

7. Lutter KS, Kerr TM, Roedersheimer LR, Lohr JM, Sampson MG, Cranley JJ. Superficial thrombophlebitis diagnosed by duplex scanning. Surgery. 1991;110(1):42-6. PMid:1866693.

8. Bergqvist $D$, Jaroszewski $H$. Deep vein thrombosis in patients with superficial thrombophlebitis of the leg. Br Med J (Clin Res Ed). 1986;292(6521):658-9. http://dx.doi.org/10.1136/bmj.292.6521.658-a. PMid:3081214

9. Gillet JL, Allaert FA, Perrin M. Superficial thrombophlebitis in non varicose veins of the lower limbs. A prospective analysis in 42 patients. J Mal Vasc. 2004;29(5):263-72. http://dx.doi.org/10.1016/ S0398-0499(04)96771-6. PMid:15738838

10. Sevestre MA, Quashié C, Genty C, Rolland C, Quére I, Bosson JL. Clinical presentation and mortality in pulmonary embolism: the Optimev study. J Mal Vasc. 2010;35(4):242-9. http://dx.doi. org/10.1016/j.jmv.2010.05.004. PMid:20598461

11. Schünemann HJ, Cook D, Grimshaw J, et al. Antithrombotic and thrombolytic therapy: from evidence to application: the Seventh ACCP Conference on Antithrombotic and Thrombolytic Therapy. Chest. 2004;126(3 Suppl):688S-96S. http://dx.doi.org/10.1378/ chest.126.3_suppl.688S. PMid:15383490

12. Hirsh J, Guyatt G, Albers GW, Harrington R, Schunemann HJ. American College of Chest Physicians Evidence-based clinical practice guidelines (8th edition). Chest. 2008;133(6 Suppl):71S-109S.

13. Guyatt GH, Akl EA, Crowther M, et al. Antithrombotictherapy and prevention of thrombosis, 9th ed: American College of Chest Physicians Evidence-Based Clinical Practice Guidelines. Chest. 2012;141(2 Suppl):7S-47S.

14. Di Nisio M, Wichers IM, Middeldorp S. Treatment for superficial thrombophlebitis of the leg. Cochrane Database Syst Rev. 2013. 4:CD004982. http://dx.doi.org/10.1002/14651858.CD004982.pub5. PMID: 23633322.

Correspondence Marcone Lima Sobreira

Rua Emílio Cani, 566, casa 2 - Vila Santa Terezinha de Menino Jesus CEP 18606-180 - Botucatu (SP), Brazil

Tel.: +55 (14) $99718-0806$ E-mail:mlsobreira@gmail.com

Author information MLS is a PhD, and an assistant professor of Vascular and Endovascular Surgery at Faculdade de Medicina de Botucatu, Universidade Estadual Paulista (UNESP) 